\title{
Increasing Water Use Efficiency in Husk Tomato (Physalis ixocarpa Brot) Production in Tabasco, Mexico with Improved Irrigation Water Management
}

\author{
Rutilo López-López ${ }^{1}$, Ignacio Sánchez Cohen2*, Marco Antonio Inzunzalbarra², \\ Andrés Fierro Álvarez ${ }^{3}$, Gerardo Esquivel Arriaga² \\ ${ }^{1}$ National Institute of Forestry, Agriculture and Livestock Research (INIFAP), Huimanguillo, México \\ ${ }^{2}$ National Center for Disciplinary Research in Soil, Water, Plant, and Atmosphere Relationships (CENID RASPA), \\ INIFAP, Gómez Palacio, México \\ ${ }^{3}$ Metropolitan Autonomous University, Unidad Xochimilco, Mexico City, México \\ Email: sanchez.ignacio@inifap.gob.mx
}

Received 22 July 2014; revised 16 August 2014; accepted 13 September 2014

Copyright (C) 2014 by authors and Scientific Research Publishing Inc.

This work is licensed under the Creative Commons Attribution International License (CC BY).

http://creativecommons.org/licenses/by/4.0/

(c) (i)

\section{Abstract}

Husk tomato production technology was developed utilizing plastic sheeting and drip irrigation based on the results of reference evapotranspiration and crop coefficients (Kc) proposed at different phenological stages. The objectives of this study were as follows: 1) to evaluate the effect of plastic sheeting on the yield of husk tomato fruit with drip irrigation based on crop evapotranspiration; 2) to validate the use of drip irrigation technology and plastic sheeting in husk tomato production using demonstration plots; and 3) to determine the profitability and economic viability of the product in the domestic market. The proposed Kc values were $0.25,0.71$ and 0.56 in the initial, intermediate and final stage of crop development, respectively. Irrigation rates ranged from 2.5 to $6 \mathrm{~mm}^{-} \mathrm{day}^{-1}$, which was equivalent to an irrigation time of 0.6 to $2.5 \mathrm{hr}$. Soil moisture tension was monitored with tensiometers at depths of 15 and $30 \mathrm{~cm}$ in a loamy eutricfluvisol. The use of plastic sheeting increased husk tomato yield by $56.2 \%$ and water productivity by $63.5 \%$ under drip irrigation conditions when basing irrigation levels on crop evapotranspiration. Soil matrix potential varied between depths of 15 and $30 \mathrm{~cm}$ based on irrigation or rainfall amounts and the use of plastic sheeting with values being higher when the plastic sheeting was used. The husk tomato fruit yield in validation plots was 46 and $54.6 \mathrm{t} \cdot \mathrm{ha}^{-1}$ with water use efficiencies rang-

\footnotetext{
*Corresponding author.
}

How to cite this paper: López-López, R., et al. (2014) Increasing Water Use Efficiency in Husk Tomato (Physalis ixocarpa Brot) Production in Tabasco, Mexico with Improved Irrigation Water Management. Journal of Water Resource and Protection, 6, 1248-1258. http://dx.doi.org/10.4236/jwarp.2014.613114 
ing from 16.1 to $19.1 \mathrm{~kg} \cdot \mathrm{m}^{-3}$. These results exceeded the national average of $14 \mathrm{t} \cdot \mathrm{ha}^{-1}$ and water use efficiency of $2.54 \mathrm{~kg} \cdot \mathrm{m}^{-3}$. With this new technology, a cost benefit ratio of 3.6 is obtained, which represents an economically profitable margin for farmers in the region.

\title{
Keywords
}

\author{
Drip Irrigation, Plastic Sheeting, Water Productivity, Profitability
}

\section{Introduction}

Water availability for agricultural purposes is getting scarcer due to more frequent weather extremes all over the world affecting precipitation patterns and/or increasing crop's evapotrasnpiration [1] [2].

It has been widely reported that increasing water use efficiency at field level is one of the alternatives to cope with rainfall uncertainty and scarce water availability i.e. [3]-[5]. In this context, improved irrigation methods along with less water demanding crops are a good alternative to increase water efficiency promoting water savings for other economic activities or to increase water availability for human consumption.

In Mexico, $50 \%$ of the territory $\left(0.98\right.$ million $\left.\mathrm{km}^{2}\right)$ is located in arid areas; nevertheless, there are areas with higher rainfall patterns that are also affected in terms of crop's yields due to the mismatch between the opportunity of rainfall occurrence and the crop water needs.

In Mexico there has been an increasing interest for planting cash crops for local consumption as well as for exporting to other states or to other countries. One of these crops is the Husk tomato (Physalis ixocarpa Brot) which under an adequate water management could be a profitable crop to be considered by farmers as an option to increase earnings.

The husk tomato (Physalisi xocarpa Brot) is a pre-Hispanic crop with an important place within the modern day vegetables produced in Mexico due to its use in the preparation of diverse dishes. The husk tomato is also grown for medicinal and craft purposes, mainly in the central portion of the country. Most of the production is destined for fresh consumption in the domestic market. In 2011, 47.830 hectares of husk tomato were planted with a national average yield of $13.93 \mathrm{t}^{\mathrm{h}} \mathrm{ha}^{-1}$ [6].

The main problems that limit husk tomato production and crop productivity are the scarcity and high cost of irrigation water as well as the inefficient management of this resource. This is especially true with well water gravity-based irrigation, which leads to high production costs due to the amount of electrical and mechanical power required. In addition, husk tomato uses irrigation levels greater than $500 \mathrm{~mm}$, which result in lower overall efficiencies.

The importance of efficient water use (EWU) in irrigation has increased in recent years, and drip irrigation methods are alternatives that contribute to the rational sustainability of water by improving agricultural irrigation efficiencies. Drip irrigation improves EWU, mainly through the efficient delivery of water volume [7]. With drip irrigation systems, both water and nutrients can be applied directly to the root zone of crops, which positively impacts performance and water savings as well as increases irrigation efficiency [8].

Understanding the optimal irrigation level is essential for profitable husk tomato production systems. Current production systems are inefficient partly because they apply high volumes of water per hectare. Irrigation efficiencies in plots are on the order of $40 \%$ due to poor system design and irrigation scheduling that is determined without reference to the water demand of the crop.

The purpose of water management irrigation with plastic sheeting is to obtain maximum yields, particularly when water is scarce. Changes in soil moisture management during crop development produce changes in yield, especially when measured as fruit production and not simply green plant matter [9].

The objectives of this study were as follows: 1) to evaluate the effect of plastic sheeting on husk tomato fruit yield when irrigated by a drip system based on crop evapotranspiration levels; 2) to validate drip irrigation technology and plastic sheeting for husk tomato crop production by establishing demonstration plots with cooperating producers; and 3) to perform an economic analysis of the profitability and economic viability of the crop in the domestic market. 


\section{Materials and Methods}

\subsection{Study Sites}

This work was performed in the town of Huimanguillo, Tabasco, which is geographically located at $17^{\circ} 50^{\prime}$ latitude and $91^{\circ} 25^{\prime}$ longitude at an altitude of $35 \mathrm{~m}$. The weather is warm and humid with abundant rainfall in summer and thermal changes in the months of December and January. The average annual temperature is $26.2^{\circ} \mathrm{C}$. The maximum monthly average temperature is $30.6^{\circ} \mathrm{C}$, which occurs in May, and the maximum and absolute minimum temperatures reach $45^{\circ} \mathrm{C}$ and $14^{\circ} \mathrm{C}$, respectively. The rate of rainfall is $2290.3 \mathrm{~mm}$ per year with September being the wettest month and April being the driest month. The annual evaporation is $1452 \mathrm{~mm}$. The highest average wind speeds are concentrated in the months of November and December at $30 \mathrm{~km} \cdot \mathrm{hr}^{-1}$. May is the least windy month with an average wind speed of $18 \mathrm{~km} \cdot \mathrm{hr}^{-1}$.

\subsection{Validation sites}

In the Fall-Winter/2012-2013 season, plastic sheeting and irrigation levels were validated in two sites based on actual crop evapotranspiration $\left(\mathrm{ET}_{\mathrm{c}}\right)$.

\subsection{Soil}

The soil where the husk tomato was grown is classified as loamy eutricfluvisol. Table 1 shows the characteristics of the soils in the two study sites. Based on soil texture, the apparent density (Da) varied from 1.35 to $1.43 \mathrm{~g} \cdot \mathrm{cm}^{-3}$, and the field capacity (FC) was 34\%. Moreover, the permanent wilting point (PWP) was $13 \%$.

\subsection{Variety}

We used the Diamond variety of husk tomato, which has a semi-erect growth habit and a medium fruit size. Trellises were constructed with wooden poles spaced at $2.5 \mathrm{~m}$ with five wires spaced at $0.3 \mathrm{~m}$ between rows. The Diamond variety was created by the Program for Genetic Improvement of Husk Tomato at the Chapingo Autonomous University.

\subsection{Ground Preparation and Suitability}

Ground preparation consisted of a fallow and three plows. Planting beds were created using a two disc plow. Drip lines and plastic sheeting were placed manually.

\subsection{Installation of Plastic Sheeting}

After constructing the seedbed and placing the irrigation lines, silver and black plastic sheeting was installed manually (Figure 1). The plastic sheeting was $2.28 \mathrm{~mm}$ thick and $1.2 \mathrm{~m}$ wide for a bed of $0.6 \mathrm{~m}$. The sheeting was perforated with holes (6 $\mathrm{cm}$ in diameter) spaced $40 \mathrm{~cm}$ apart, and the sheeting roll was $915 \mathrm{~m}$ long. The benefits of plastic sheeting are reduced soil evaporation, reduced weed growth and earlier maturity of the crop.

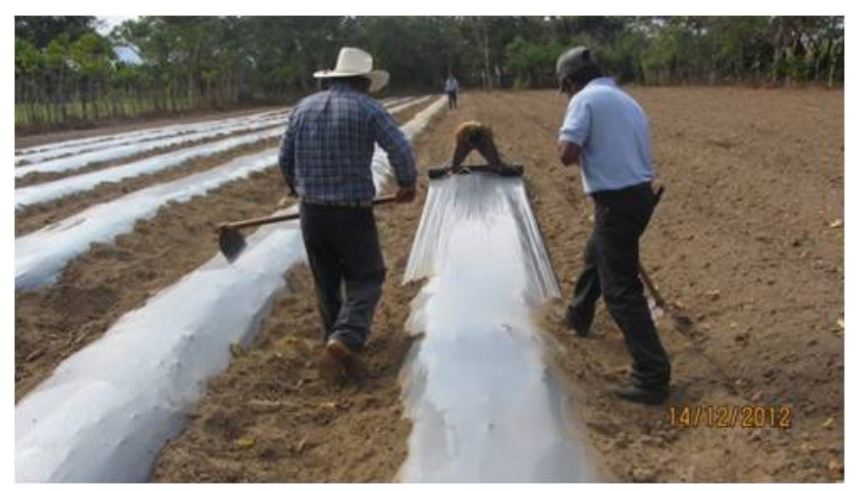

Figure 1. Installing the drip line and plastic sheeting for growing husk tomato in a demonstration plot. 
Table 1. Physical and chemical properties of the soil at a $30 \mathrm{~cm}$ depth in the study sites.

\begin{tabular}{cccccccccccc}
\hline Site & Sand & Clay & Silt & $\mathrm{pH}$ & $\mathrm{MO}$ & $\mathrm{NO}_{3}$ & $\mathrm{NH}_{4}$ & $\mathrm{~S}$ & $\mathrm{P}$ & $\mathrm{Ca}$ & $\mathrm{K}$ \\
& & $\%$ & & & $\%$ & & $\mathrm{cmol}^{2} \mathrm{~kg}^{-1}$ & & $\mathrm{mg}^{-1} \mathrm{~kg}^{-1}$ \\
\hline CE H. & 47.1 & 36.6 & 16.3 & 6.4 & 1.2 & 10.6 & 16.1 & 15.1 & 15.2 & 16.0 & 0.50 \\
Ej. H & 67.5 & 9.8 & 22.7 & 5.9 & 0.95 & & & & 20.7 & 12.7 & 0.45 \\
\hline
\end{tabular}

\subsection{Tray Sowing and Transplantation}

Husk tomato seeds were sown in trays with 50 and 200 cavities. The substrate used was peat moss and vermiculite (1:1) in 107 L packets. Trays were covered with dark plastic and stacked. After the seeds germinated on the third day, the trays were unstacked and transferred to the nursery. The seedlings were watered with a nutrient solution (Steiner) diluted to $50 \%$ to avoid burn injury. Seedlings were transplanted at 30 days after sowing (Table 2). The characteristics of seedlings at the time of transplant were as follows: $10 \mathrm{~cm}$ in height, $2.7 \mathrm{~mm}$ in diameter and at least six fully expanded true leaves. The planting arrangement of the seedlings with drip irrigation and plastic sheeting was $1.5 \mathrm{~m}$ between rows and $0.40 \mathrm{~m}$ between plants (Figure 2) for a population of 16,500 plants per hectare.

\subsection{Irrigation}

To estimate crop water needs, we used the class “A” evaporimetric pan method. Equation (1) was used to calculate the reference evapotranspiration $\left(E T_{0}\right)$ as follows:

$$
E T_{0}=E v \cdot K_{t}
$$

where $E v$ is the daily evaporation obtained from a pan at the meteorological station of CONAGUA located in the Huimanguillo Experimental Field in Tabasco; and $K_{t}$ is the coefficient of the pan assumed to be 0.8 [10] [11], based on the climate of the region. The values of the crop coefficient, $K c$, were obtained from [12] for husk tomato cultivation. The $K c$ values were $0.25,0.71$ and 0.56 in the initial, intermediate and final stage of crop development, respectively. In addition to the $K c$ values, $E T_{c}$ was estimated according to Equation (2):

$$
E T_{c}=E T_{0} \cdot K_{C}
$$

The irrigation levels applied to the crops ranged from 2.5 to $6 \mathrm{~mm} \cdot$ day $^{-1}$, which was equivalent to an irrigation run time of 0.6 to $2.5 \mathrm{hr}$, and the irrigation method was by drip lines (Figure 3). Uniformity efficiently was $88 \%$ as evaluated by the method proposed by [13]. The nominal characteristics were as follows: internal diameter of 16 $\mathrm{mm}$, thickness of $6 \mathrm{~mm}$, flow rate of $1.02 \mathrm{~L} \cdot \mathrm{ha}^{-1}$, emitter spacing of $0.2 \mathrm{~m}$ and nominal pressure of $0.8 \mathrm{~Pa}$.

For monitoring soil moisture, tensiometers were placed 15 and $30 \mathrm{~cm}$ deep (Figure 2) in two points of each plot. The soil moisture tension in the top layer of soil $(15 \mathrm{~cm})$ ranged from 0 to $22 \mathrm{kPa}$ throughout the crop cycle, and the soil moisture tension varied between -6 and $-35 \mathrm{kPa}$ in the $30 \mathrm{~cm}$ layer of soil. The soil moisture tension values indicated that the irrigation levels applied to the plots were sufficient to meet the water requirements of the crop. Hence, the effort expended by the plant to absorb water through its roots did not reach critical moisture tension levels, and it was not less than the field capacity $(<-33 \mathrm{KPa})$.

\subsection{Fertigation}

Nutrient application through irrigation water occurred by injecting fertilizer solutions through a Ventury [injector] or a pump. Background or base fertilization consisted of the application of $100 \mathrm{~kg}$ of diammonium phosphate (DAP), which was equivalent to $18 \mathrm{~kg}$ of nitrogen and $46 \mathrm{~kg}$ of phosphorus, at the time of construction of the beds and placement of the plastic sheeting. The fertilization formula applied during fertigation was 200-150-80 [14] distributed according to the phenological stage of the crop (initial, intermediate and final). The sources of soluble fertilizer were 8-24-00 liquid ammonium sulfate (21-00-00-22), monoammonium phosphate (12-60-00), potassium nitrate (13-00-46) and 20\% phosphoric acid. Fertigation was applied twice a week, and fertilizer injection was through a pump with a $200 \mathrm{~L}$ tank. 


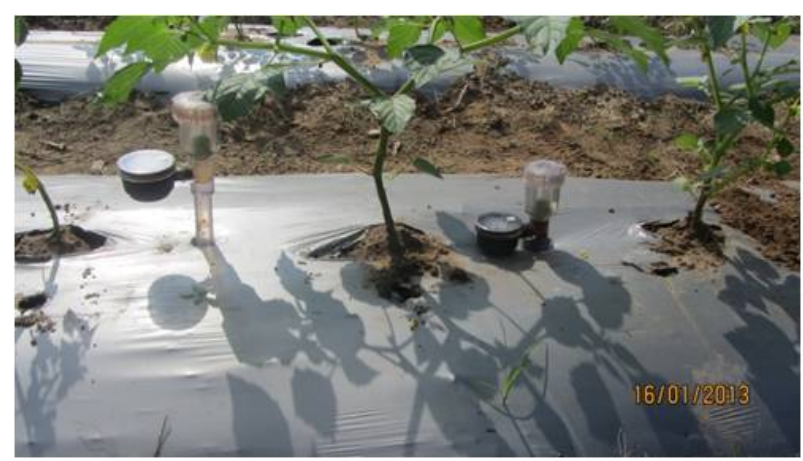

Figure 2. Monitoring soil moisture tension at two depths (15 and $30 \mathrm{~cm}$ ) in husk tomato cultivation.

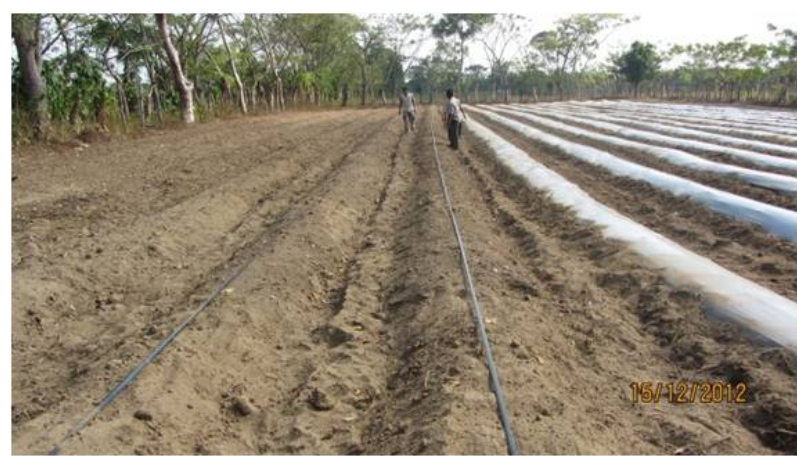

Figure 3. Drip line irrigation system and plastic sheeting.

Table 2. Date of emergence and husk tomato seedling transplantation in different study sites.

\begin{tabular}{ccc}
\hline Site/Growing cycle & Emergence Date & Transplantation Date \\
\hline C.E. Huimanguillo F-W/2011-2012 & 15 November 2011 & 16 December 2011 \\
Ej. Huimanguillo F-W/2012-2013 & 17 November 2012 & 18 December 2012 \\
C.E. Huimanguillo F-W/2012-2013 & 13 January 2013 & 15 January 2013 \\
\hline
\end{tabular}

\subsection{Control of Pests and Diseases}

Direct control of pests and diseases was performed with trap crops of maize (Zea mays L.) and applications of insecticides, such as cypermethrin, endosulfan and methamidophos at $0.5,1$ and $1 \mathrm{~L} \cdot h a^{-1}$, respectively. The broad mite (Polyphagotarsonemus latus) was controlled with spirodiclofen (Envidor) and abamectin (hortimec) at doses of 240 a.i. ha $^{-1}$ and $1 \mathrm{~L} \cdot \mathrm{ha}^{-1}$, respectively. The white fly (Bemiciatabaci) was controlled at the end of crop cycle (April) with insecticides based on imidacloprid, deltamethrin and ethyl chlorpyrifos plus permethrin. All chemicals were applied by spraying with backpack pumps at the manufacturer-recommended doses during the morning.

\subsection{Harvest}

Harvest began when a high percentage of fruit filled the calyx (bag) covering it. The number of subharvests ranged from 9 - 11 depended on the treatments and study sites. The subharvests at the producer site took place from February 12 to March 30, 2013. In the Huimanguillo Experimental Field, the subharvests took place from April 1 to May 29, 2013. At both sites, the subharvests averaged one per week.

\subsection{Experimental Design and Treatments}

We assessed treatments with and without plastic sheeting during the F-W/2011-2012 cycle, and these treatments were distributed in a completely randomized design with four replications. The experimental unit consisted of 
three rows (each $5 \mathrm{~m}$ long; $15 \mathrm{~m}^{2}$ ) with four replications, and the fruit yield was recorded by subharvest and total harvest. In the F-W/2012-2013 cycle, we validated the use of plastic sheeting and irrigation levels based on crop evapotranspiration at two sites.

\subsection{Measurement of Variables}

Soil moisture tension was monitored at two depths $(15$ and $30 \mathrm{~cm})$. Irrigation levels were calculated (from the crop evapotranspiration) from the $E T_{0}$ and crop coefficients proposed. Precipitation levels were obtained from the weather station at the Huimanguillo Experimental Field. The fruit yield was obtained from the subharvests made during the harvest period. Direct costs plus investment costs and net income based on an average product price of $\$ 1.13$ were obtained. Efficient use of irrigation water was defined as the yield of green fruit $(R f)$ in $\mathrm{kg} \cdot \mathrm{ha}^{-1} \mathrm{ob}-$ tained per total irrigation level $(L t)$ in $\mathrm{m}^{3} \cdot \mathrm{ha}^{-1}$ applied from transplant to harvest not including the amount of rain fall.

$$
E W U=\frac{R f}{L t}
$$

\subsection{Statistical and Economic Analysis}

Analysis of variance (F-test) and Student t-tests for the two populations were performed using the Statistic Analysis System [15] program for variable fruit yield and efficient use of irrigation water. Treatment means were compared using Tukey's test $(\mathrm{P}<0.05)$. Economic evaluation was performed by the income analysis method for annual crops projected out to five years.

\section{Results and Discussion}

\subsection{Effect of Plastic Sheeting on Fruit Yield}

Figure 4 shows the comparison of fruit yield by subharvest. Using the t-test for comparing two populations under the assumption of equal variances, we found that there were highly significant differences $(P=0.004)$ due to the effect of plastic sheeting. The effect was apparent in the maturity of the first subharvest where the population without plastic did not produce any fruit. The husk tomato fruit yield with plastic sheeting averaged $32.1 \mathrm{t} \cdot \mathrm{ha}^{-1}$ compared to $14.1 \mathrm{t}^{\mathrm{t}} \mathrm{ha}^{-1}$ obtained from the treatment without plastic sheeting (Figure 4), which resulted in an increase of $56.2 \%$, and the efficient water use increased by $63.5 \%$ compared to drip irrigation conditions that did not use plastic sheeting. This result was consistent with [14] who concluded that the use of plastic sheeting increases husk tomato fruit yield by an average of $56 \%$ and water productivity by $57 \%$.

Confidence intervals with a significance level $(\alpha)$ of 0.05 for the population without plastic sheeting ranged from 10.9 to $17.3 \mathrm{t} \cdot \mathrm{ha}^{-1}$, and the confidence intervals ranged from 19.5 to $44.6 \mathrm{t} \cdot \mathrm{ha}^{-1}$ for the treatment with plastic sheeting with a weighted standard deviation of $3.6 \mathrm{t} \cdot \mathrm{ha}^{-1}$ (Figure 5).

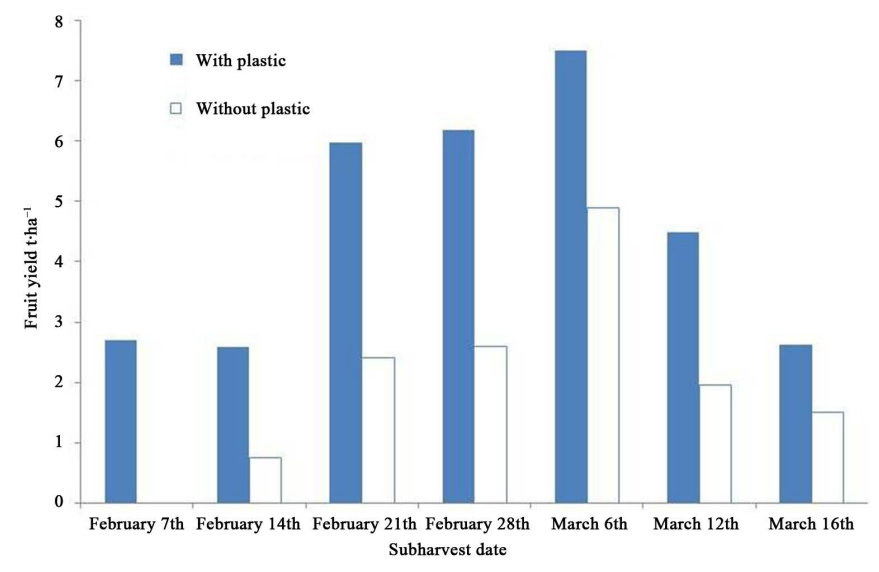

Figure 4. Effect of plastic sheeting on husk tomato fruit yield by subharvest with drip irrigation in the F-W/2011-2012 cycle. 


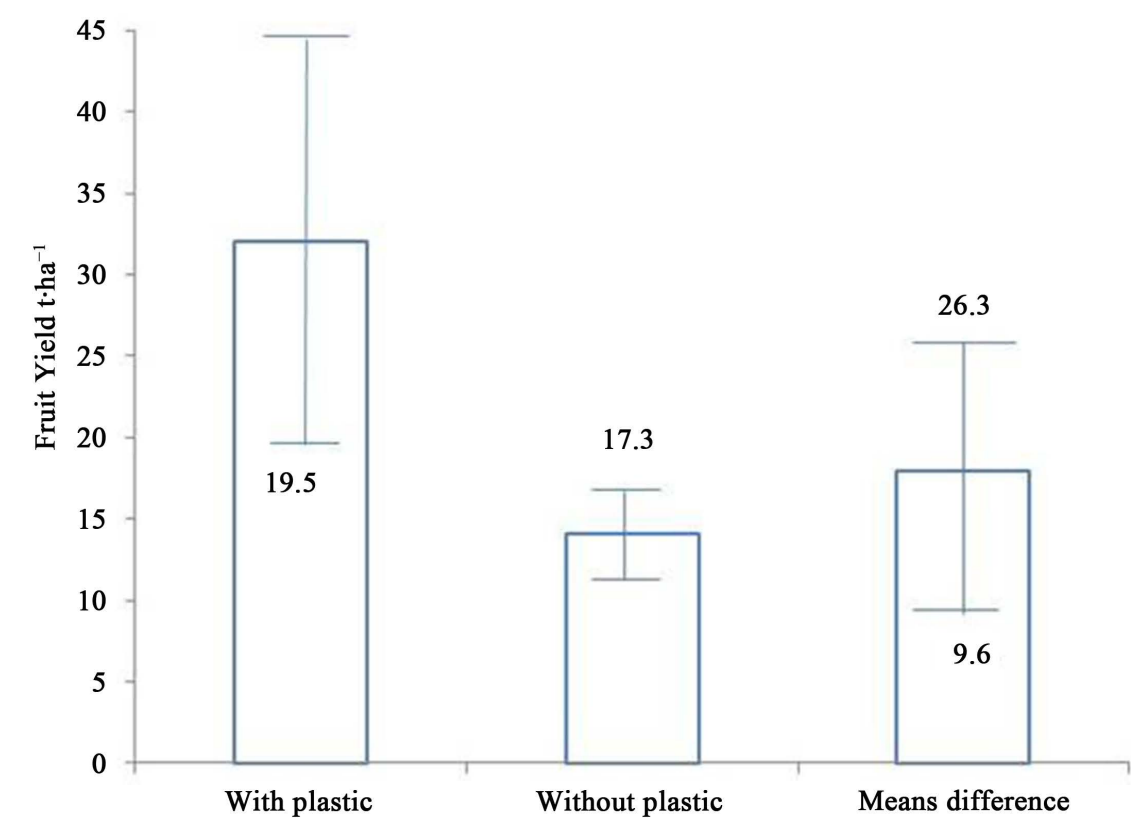

Figure 5. Effect of plastic sheeting on total yield (7 subharvests) of husk tomato fruits with drip irrigation during the F-W/2011-2012 cycle at the Huimanguillo Experimental Field, Tabasco, Mexico.

\subsection{Irrigation Management}

Figure 6 shows the effect of rain and irrigation on the soil matrix potential and soil moisture tension measured with tensiometers at depths of 15 and $30 \mathrm{~cm}$. The total amount of rainfall during the crop cycle in the F-W/20112012 cycle was $217 \mathrm{~mm}$, and $60 \%$ of the rainfall occurred in the first stage of the crop. The total amount of irrigation applied was $255 \mathrm{~mm}$ based on crop evapotranspiration. There were variations in the values of soil matrix potential at the two depths due to the effect of irrigation and rain levels. In general, the values at $15 \mathrm{~cm}$ were similar in both populations with and without plastic sheeting, especially in the initial stage of the crop. However, at the $30 \mathrm{~cm}$ depth, the soil matrix potentials were greater in the system with plastic sheeting. Applying irrigation levels based on crop evapotranspiration for both treatments (with and without plastic sheeting) maintained levels of matrix potential near field capacity $(<33 \mathrm{kPa}$ ) during the crop cycle.

The matrix potential during most of the crop cycle was greater than $-30 \mathrm{kPa}$ at the $15 \mathrm{~cm}$ depth and greater than $-50 \mathrm{kPa}$ at the $30 \mathrm{~cm}$ depth, mainly in the treatment without plastic sheeting. The latter value is considered deficient and can negatively affect fruit yield (López-López et al., 2009), especially if conditions of high tension remain for extended periods [16].

The soil matrix potential values were directly related to the irrigation regimen established, thereby indicating that the irrigation levels were sufficient to maintain moisture levels suitable for crop growth and fruit yield. However, when considering productivity and efficient use of water, plastic sheeting was a better option than no covering [14].

Figure 7 shows the effect of rain and irrigation on the matrix potential measured with tensiometers at the 15 and $30 \mathrm{~cm}$ depths. The total amount of rainfall during the growing season (O-I/2012-2013) was $288.5 \mathrm{~mm}$. The total amount of irrigation applied to the crop was $366 \mathrm{~mm}$ based on crop evapotranspiration. In the first soil layer (15 $\mathrm{cm}$ ), the moisture tension varied from 0 to $-20 \mathrm{kPa}$ during the crop cycle. In the $30 \mathrm{~cm}$ soil layer, the moisture tension ranged from -10 to $-30 \mathrm{kPa}$, which approached field capacity $(-33 \mathrm{kPa})$. The moisture tension values indicate the effort that the plants must exert to absorb water through their roots.

Irrigation levels delivered each day ranged from 3 to $6 \mathrm{~mm}$ in accordance with calculations of crop evapotranspiration. Using plastic sheeting-based crop coefficients $(0.25,0.71$ and 0.56 in the initial stage, middle stage and end of culture, respectively; [12] the efficiency of irrigation increased resulting in a water savings of approximately $25 \%$ compared with crop coefficients proposed by [10] for tomato cultivation $(0.6,1.15$ and 0.8 , respectively). 


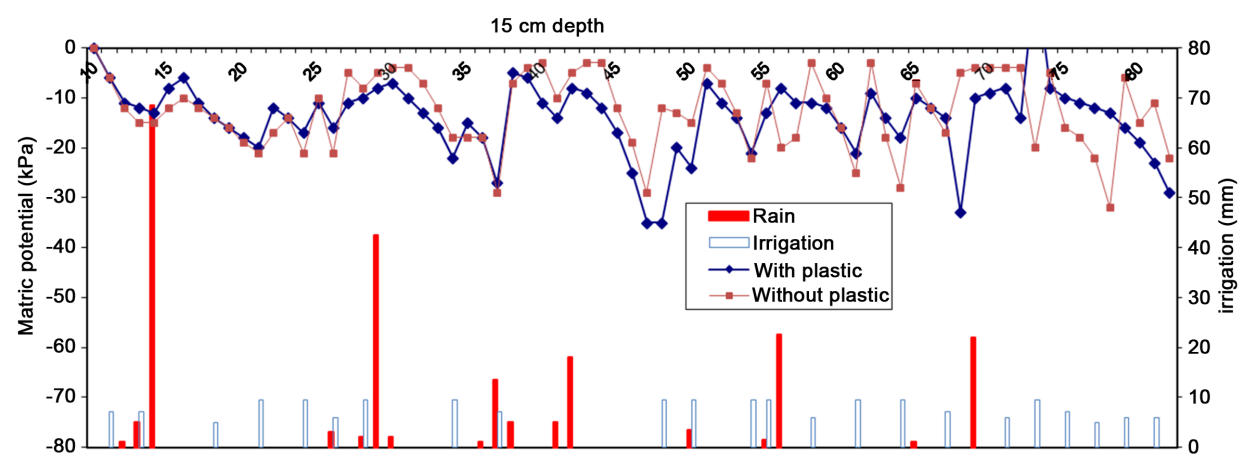

Julian day

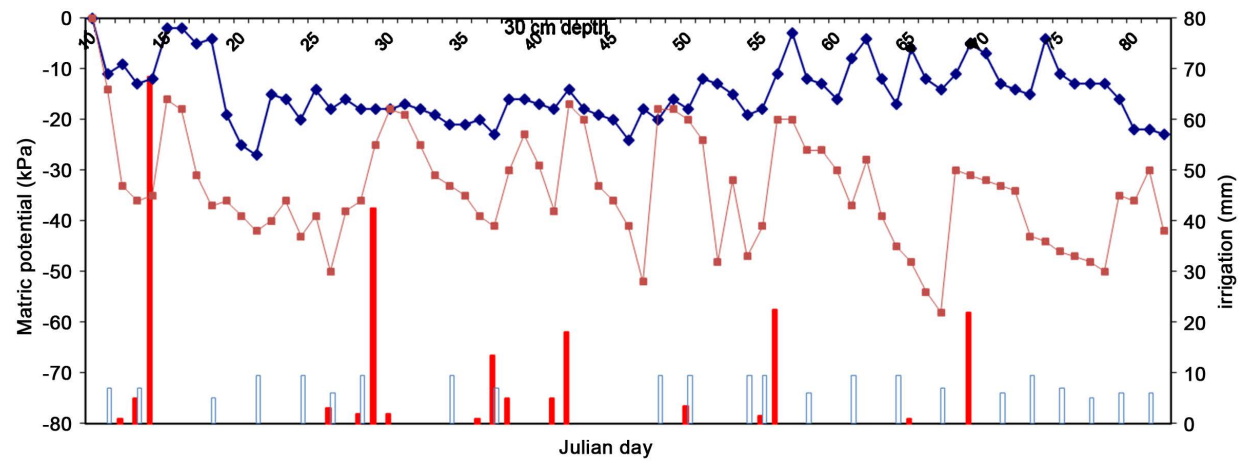

Figure 6. Effect of irrigation level and rain on the soil matrix potential with and without plastic sheeting at depths of 15 and $30 \mathrm{~cm}$.
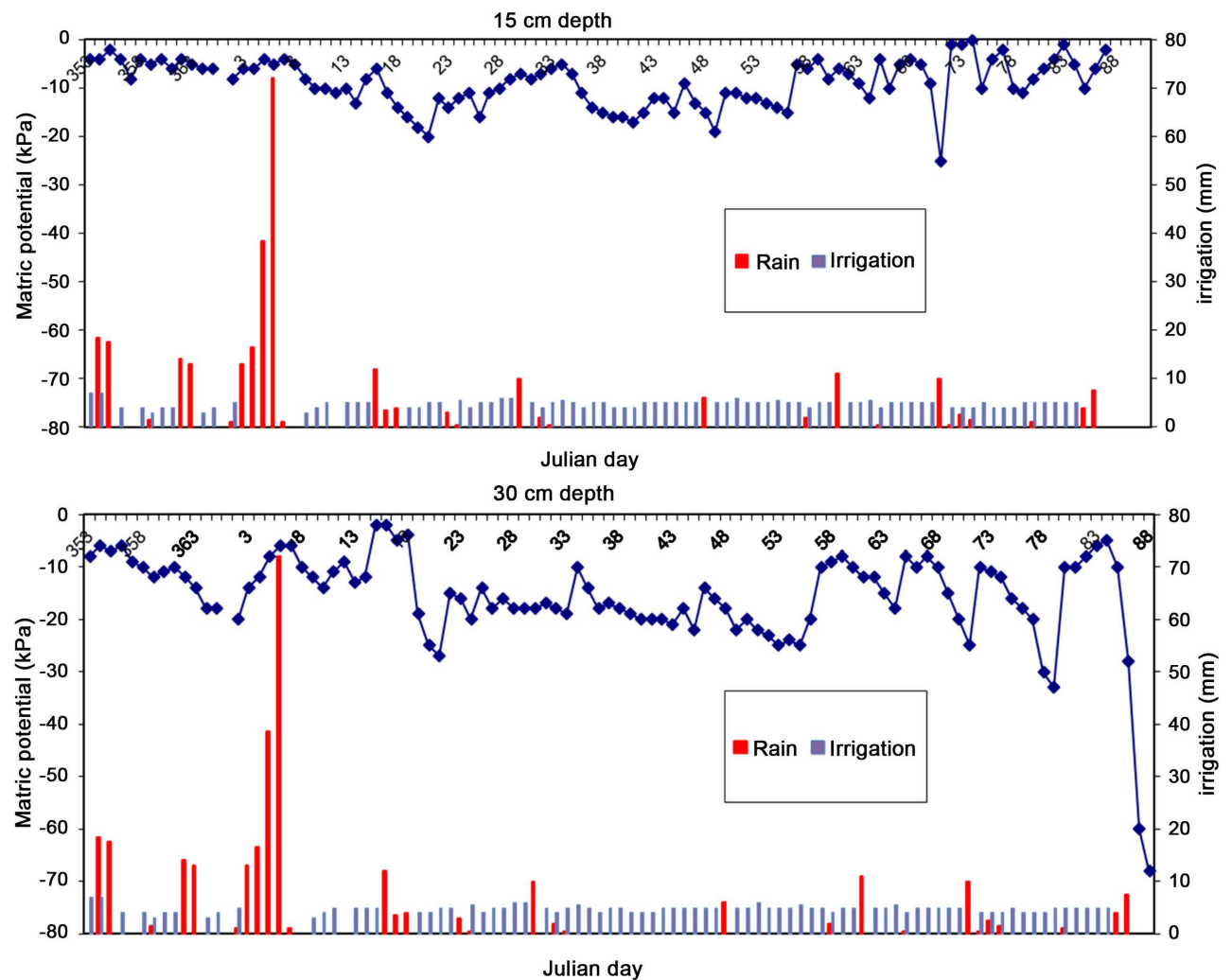

Figure 7. Effect of irrigation and rain levels on the soil matrix potential at two depths $(15$ and $30 \mathrm{~cm})$ in the cultivation of husk tomato with drip irrigation and plastic sheeting in 2013. 


\subsection{Validation of the Efficient Use of Irrigation Water}

Figure 8 and Figure 9 shows the husk tomato fruit yield by sub harvest during the F-W/2012-2013 cycle in the plot of a cooperating producer (Ejido Huimanguillo) and in the Huimanguillo Experimental Field, respectively. There were 8 and 11 sub harvests per site (Ejido Huimanguillosite and the Huimanguillo Experimental Field, respectively) with total yields ranging from 0.5 to $10 \mathrm{t} \cdot \mathrm{ha}^{-1}$ during the crop cycle.

Figure 10 compares the average yields of the validation sites. Forthe Ejido Huimanguillo site, the average yield was $46.05 \mathrm{t} \cdot \mathrm{ha}^{-1}$ compared to an average yield of $54.6 \mathrm{t} \cdot \mathrm{ha}^{-1}$ at the Huimanguillo Experimental Field.

In contrast to the national average yield of $14 \mathrm{t} \cdot \mathrm{ha}^{-1}$ and water use efficiency of $2.54 \mathrm{~kg} \cdot \mathrm{m}^{-3}$ coupled with the poor quality of fruit from traditional systems (gravity irrigation) or rain fed systems, the plastic sheeting production technology together with drip irrigation increased fruit yield by $69.6 \%$ and $74.3 \%$ in the Ejido Huimanguillo and Huimanguillo Experimental Field study sites, respectively. The irrigation water use efficiency increased by $63.5 \%$ with a conversion efficiency of 16.1 and $19.1 \mathrm{~kg} \cdot \mathrm{m}^{-3}$ at the Ejido Huimanguillo and Huimanguillo Experimental Field study sites, respectively.

The difference in fruit yield at the Ejido Huimanguillo and Huimanguillo Experimental Field sites may be due to the physical and chemical characteristics of the soil given that the soil at the Huimanguillo Experimental Field has more nutrients, especially nitrogen, potassium, calcium and magnesium. This soil also has a higher moisture retention capacity, which favors better growth and development of the crop. These yields were consistent with those reported by [17] in North and Central Mexico when growing husk tomato with drip irrigation systems and plastic sheeting. These authors achieved yields up to $42 \mathrm{t} \cdot \mathrm{ha}^{-1}$, and the use of trellises and fertigation systems increased the yields up to 60 and $80 \mathrm{t} \cdot h \mathrm{a}^{-1}$.

\subsection{Economic Evaluation}

Direct cultivation expenses were $\$ 4.281$ per hectare plus investment costs of $\$ 2.270$ per hectare. Direct cultivation expenses correspond to steps starting at land preparation and proceeding through seedling production in trays, plastic sheeting, fertigation, pest control, disease control and harvesting. Investment expenditures correspond to the construction of a well (4 in diameter and $18 \mathrm{~m}$ deep) plus purchase of the drip irrigation system.

Economic analysis (Table 3) indicated that the plastic sheeting and drip irrigation cultivation practices were profitable from the first year assuming a yield of $42 \mathrm{t}^{\mathrm{h}} \mathrm{ha}^{-1}$ and an average price of $\$ 0.62 \mathrm{per} \mathrm{kg}$. The cash flow was positive from the first year $\left(\$ 19.296 \mathrm{ha}^{-1}\right)$, and attractive financial efficiency indicators were obtained. For example, a cost benefit ratio of 3.7 was obtained compared to a traditional system with an average yield of $14 \mathrm{t}^{\mathrm{h}} \mathrm{ha}^{-1}$ and cost benefit ratio of only 1.6.

The profitability of growing husk tomato is higher if plastic sheeting is used and seedlings are transplanted in the months of September to January because the profitability reaches an average field price of $\$ 0.90$ per kg of ripe fruit.

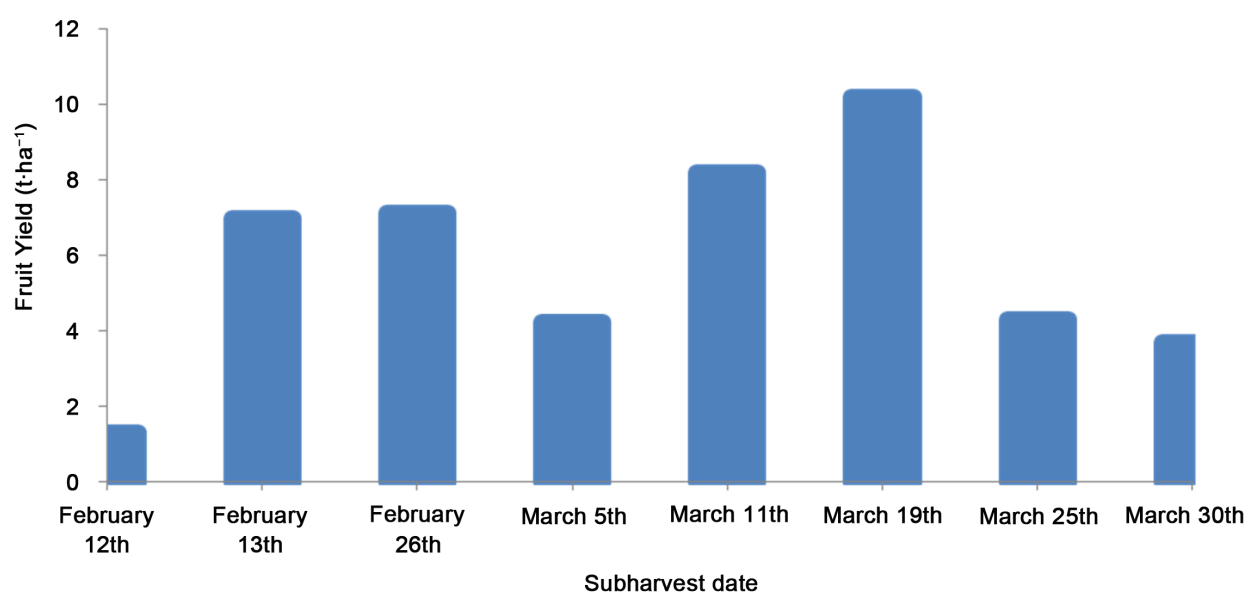

Figure 8. Husk tomato fruit yield $\left(\mathrm{t} \cdot \mathrm{ha}^{-1}\right)$ by subharvest with drip irrigation and plastic sheeting in the F-W/2012-2013 cycle at the Ejido Huimanguillo site. 


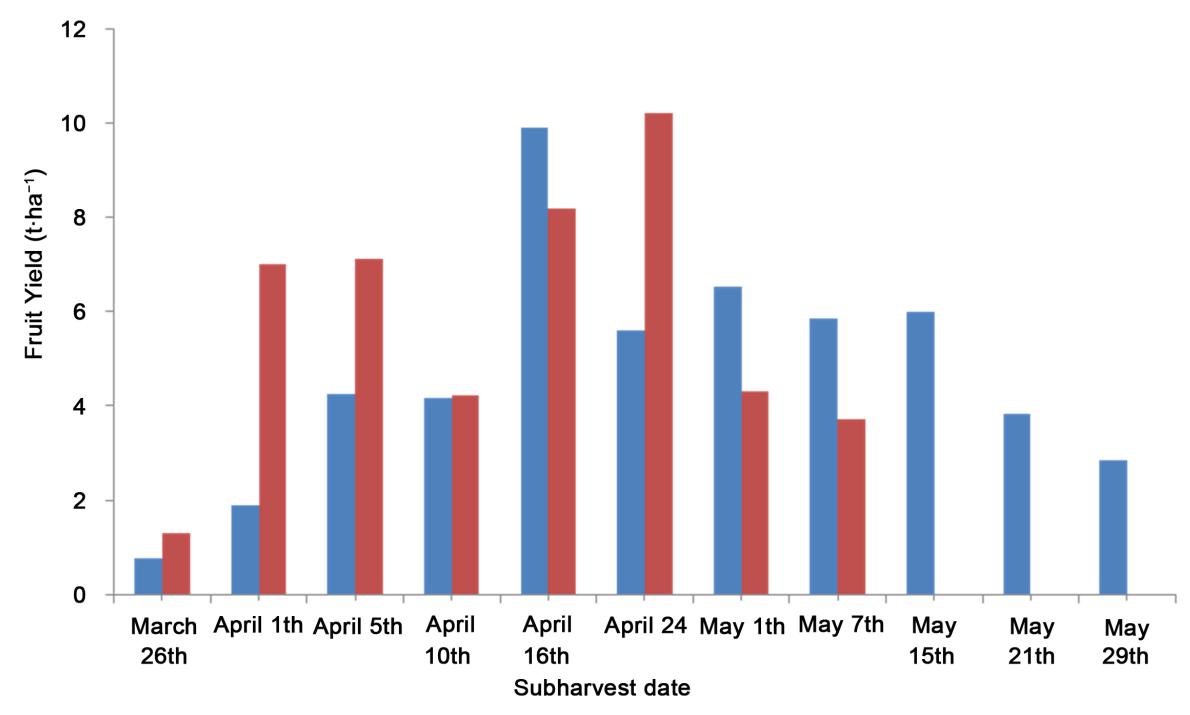

Figure 9. Husk tomato fruit yield $\left(\mathrm{t} \cdot \mathrm{ha}^{-1}\right)$ by subharvest with drip irrigation and plastic sheeting in the F-W/2012-2013 cycle at the Huimanguillo Experimental Field.

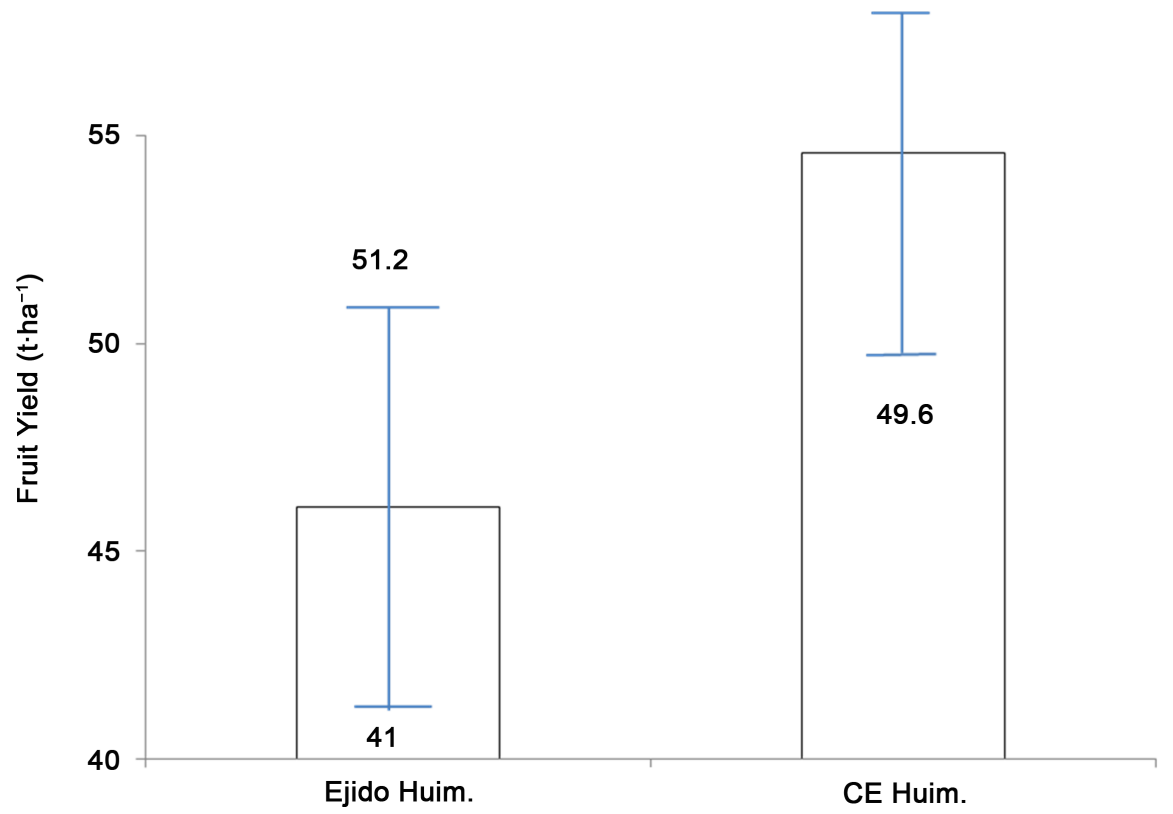

Figure 10. Average total husk tomato fruit yield of the study sites in the F-W/2012-2013 cycle.

Table 3. Profit analysis of husk tomato crop with drip irrigation and plastic sheeting for two transplant dates.

\begin{tabular}{ccc} 
Concept & New System & Traditional System \\
\hline Internal rate on return \% (IROR) & 280.7 & 56.8 \\
Net present value (NPV) & 42.844 & 1.62 \\
Cost-benefit ratio (CBR) & 3.7 & 31.057 \\
NPV of the benefits & 74.773 & 19.153 \\
NPV of the expenses & 20.238 & \\
\hline
\end{tabular}




\section{Conclusions}

Plastic sheeting increased husk tomato fruit yield by $56.2 \%$ and water productivity by $63.5 \%$ when applying irrigation levels based on crop evapotranspiration via drip irrigation.

The soil matrix potential varied between depths of 15 and $30 \mathrm{~cm}$ based on the amount of rain or irrigation as well as the use of plastic sheeting. Higher values (less negative) were measured when plastic sheeting was used.

The husk tomato fruit yields in the validation plots were 46 and $54.6 \mathrm{t} \cdot \mathrm{ha}^{-1}$ with water use efficiency values of 16.1 and $19.1 \mathrm{~kg} \cdot \mathrm{m}^{-3}$, respectively. These results exceeded the national average of $14 \mathrm{t} \cdot \mathrm{ha}^{-1}$ and water use efficiency of $2.54 \mathrm{~kg} \cdot \mathrm{m}^{-3}$.

With this new technology, a cost benefit ratio of 3.6 is obtained, which represents an economically profitable activity for farmers in the region.

\section{References}

[1] Corcobado, T., Cubera, E., Juarez, E., Moreno, G. and Soila, A. (2014) Drought Events Determine Performance of Quercus Ilex Seedings and Increase Their Suceptibility to Phytophtoracinnamomi. Agricultural and Forest Meteorology, 192-193, 1-8. http://dx.doi.org/10.1016/j.agrformet.2014.02.007

[2] Potop, V., Mozny, M. and Soukup, J. (2012) Drought Evolution at Various Time Scales in the Lowland Regions and Their Impact on Vegetable Crops in the Czech Republic. Agricultural and Forest Meteorology, 158, 121-133. http://dx.doi.org/10.1016/j.agrformet.2012.01.002

[3] Gómez, M., Pérez-Expósito, M.A., Hammami, S.B., Centeno, A. and Rapoport, H.F. (2014) Effect of Varied Summer Deficit Irrigation on Components of Olive Fruit Growth and Development. Agricultural Water Management, 137, 8491.

[4] Causape, J. and Aragués, D.Q.R. (2014) Assessment of Irrigation and Environmental Quality at the Hydrological Basin Level: I. Irrigation Quality. Agricultural Water Management, 70, 195-209. http://dx.doi.org/10.1016/S0378-3774(04)00177-5

[5] Nair, S., Jhonson, J. and Wang, C. (2012) Efficiency of Irrigation Water Use: A Review from the Perspectives of Multiple Disciplines. Agronomy Journal, 105, 351-363. http://dx.doi.org/10.2134/agronj2012.0421

[6] (2012) SIAP: Servicio de Información Agroalimentaria y Pesquera. Produción Agrícola Anual 2012. Tomate Verde. www.siap.gob.mx/

[7] Stanghellini, C., Kempkes, F.L.K. and Knies, P. (2003) Enhancing Environmental Quality in Agricultural Systems. Acta Horticulturae, 609, 277-283.

[8] Phene, C.J. and Howell, T.A. (1984) Soil Sensor Control of High Frequency Irrigation. Transactions of the ASABE, 27, 392-396. http://dx.doi.org/10.13031/2013.32798

[9] Flinn, J.C. and Musgrave, W.F. (1967) Development and Analysis of Input-Output Relation for Irrigation Water. Australian Journal of Agricultural and Resource Economics, 11, 1-20.

[10] Allen, R.G., Pereira, L.S., Raes, D. and Smith, M. (1998) Crop Evapotranspiration. FAO Irrigation and Drainage Paper No. 56. FAO, Rome.

[11] Doorenbos, J. and Pruitt, W.O. (1975) Guidelines for Predicting Crop Water Requirements. FAO Irrigation and Drainage Paper No. 24, FAO, Rome.

[12] López-López, R., Arteaga-Ramírez, R., Vázquez-Peña, M.A., López-Cruz, I.L. and Sánchez-Cohen, I. (2010) Evapotranspiración del cultivo de tomate de cáscara (Physalis ixocarpa Brot) estimada mediante el potencial mátrico del suelo. Revista Fitotecnia Mexicana, 33, 157-168.

[13] Karmeli, D. and Keller, J. (1975) Trickle Irrigation Design. 1st Edition, Rain Bird Sprinkler Manufacturing Corporation, Glendora, 133 p.

[14] López-López, R., Arteaga-Ramírez, R., Vázquez-Peña, M.A., López-Cruz, I.L. and Sánchez-Cohen, I. (2009) Producción de tomate de cáscara (Physalis ixocarpa Brot.) basado en láminas de riego y acolchado plástico. Revista Chapingo Serie Horticultura, 15, 83-89. http://dx.doi.org/10.5154/r.rchsh.2009.15.011

[15] SAS Institute Inc. (2008) SAS/STAT® 9.2. User’s Guide. SAS Institute Inc., Cary.

[16] Gratacos, E. and Gurovich, L. (2003) Uso de la técnica del fitomonitor como indicador del estado hídrico del kiwui y su uso en Riego programado. Ciencia e Investigación Agraria, Chile, 30, 113-137. Hernández, J.F.S. and Yáñez, S.B. (2009) Aprovechamiento tradicional de las especies de Physalis en México. Revista de Geografía Agrícola, 43, 81-86.

[17] Castro-Brindis, R., Sánchez-García, P., Peña-Lomelí, A., Alcantar-González, G., Baca-Castillo, G. and López Romero, R.M. (2000) Niveles críticos de suficiencia y toxicidad de $\mathrm{N}-\mathrm{NO}_{3}$ en el extracto celular de pecíolos de tomate de cáscara. Revista Terra, 18, 141-146. 
Scientific Research Publishing (SCIRP) is one of the largest Open Access journal publishers. It is currently publishing more than 200 open access, online, peer-reviewed journals covering a wide range of academic disciplines. SCIRP serves the worldwide academic communities and contributes to the progress and application of science with its publication.

Other selected journals from SCIRP are listed as below. Submit your manuscript to us via either submit@scirp.org or Online Submission Portal.
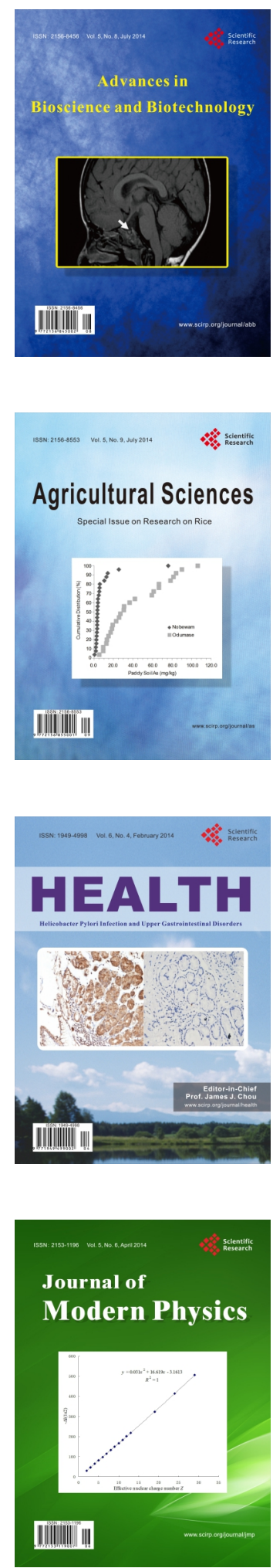
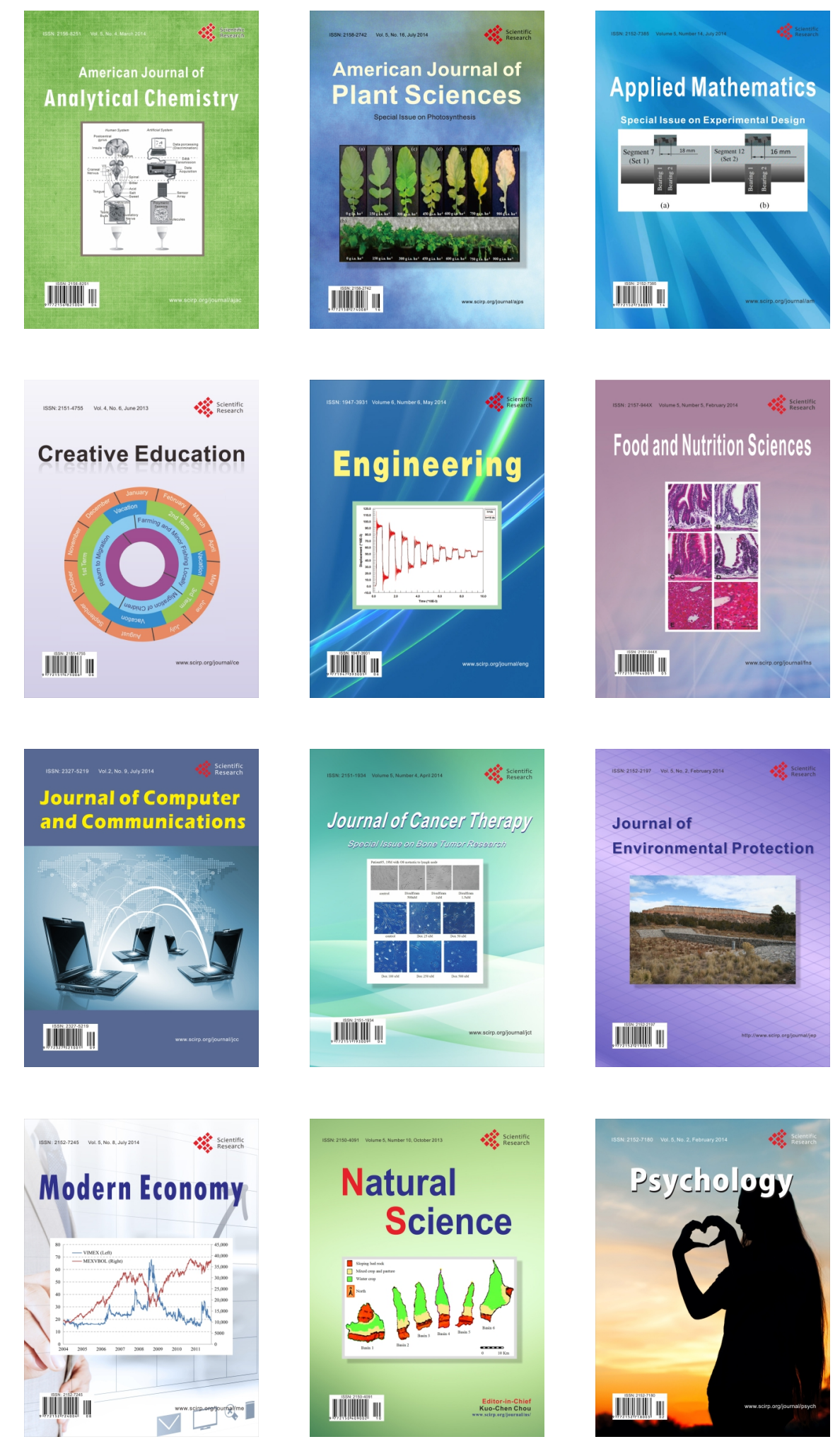